\title{
Land Suitability Analysis for Mung Bean Production Using a GIS Based Multi-Criteria Technique in Part of Wollo, Amhara Region, Ethiopia
}

\author{
Wondim Alemu Ayenew \\ School of Land Administration, Woldia University, PO box 400, Woldia, Ethiopia \\ Hailu Ayene \\ Geography and Environmental study, Wollo University, Po box 1145, Dessie, Ethiopia \\ Kassahu Wubalem \\ Geography and Environmental study, Debremarkos University, Pobox 290, Debremarkos, Ethiopia
}

\begin{abstract}
The land has been always a basic factor for growing crops. The term land suitability can be defined in this regard as the ability of a particular type of land to support for a specific use, and the land suitability classification process involves the evaluation and grouping of a particular land area in terms of their suitability for a defined use. Land suitability is a description of compatibility level of a land for certain utilization. For the present research work areas spatially suitable for the Mung bean for low land crop identified using GIS tools. Food security is not just an economic problem but also a social and political issue relates in the country. Ensuring food security for all is one of the major challenges that our Country (Ethiopia) faces today, production of surplus in the areas like this study conducted (part of Wollo) is one of the problem solve by researches. Remotely sensed data (Landsat images), Digital elevation model and soil data was loaded and processed in GIS software i.e. Arc10.5 version and ERDAS 2015 was used for land cover map development. MCDM based AHP methods have used for spatial analysis in agriculture. Using the weights generated from AHP for the various parameters, the maps of soil (texture and depth), Climatic factors (climate and Temperature) and topographic (slope and altitude) were overlaid to generate the final Green gram suitability map of the Whole Wollo.
\end{abstract}

Keywords: Land suitability, GIS tools and AHP

DOI: $10.7176 / \mathrm{JESD} / 11-23-04$

Publication date: December $31^{\text {st }} 2020$

\section{Introduction}

The population of the planet is growing dramatically and in order to meet the increasing demand for food, the farming community has to produce more and more. However, under present situation where land is scarce, it is impossible to bring more area under cultivation to satisfy the growing demand (Teka \& Haftu 2012).

The land has been always a basic factor for growing crops. The term land suitability can be defined in this regard as the ability of a particular type of land to support for a specific use, and the land suitability classification process involves the evaluation and grouping of a particular land area in terms of their suitability for a defined use (Prakash, 2003).

Matching the land characteristics with the crop requirements gives the suitability. So, 'suitability' is a measure of how well the qualities of a land unit match the requirements of a particular form of land use (FAO, 1976). MacDonald (2006) defined land suitability analysis as the separation of the nature or quality of land into its component parts based on the land's ability to serve a particular use or purpose.

According to Asfaw et al. (2012) in Ethiopia Mungbean is mostly grown by smallholder farmers under drier marginal environmental condition and the production capacity is lower than other pulse crops. Green Mung bean is less used domestically, but it is a common ingredient in Chinese and Indian cuisines.

Land suitability is a description of compatibility level of a land for certain utilization. For the present research work areas spatially suitable for Mung bean of low land crop were identified using GIS tools with Mult-criteria decision making techniques.

In Ethiopia, agricultural land suitability analysis is very important since agriculture accounts on average for about $46.3 \%$ of Gross Domestic Product, $83.9 \%$ of exports and $80 \%$ of the labor force (MoFED, 2009). In the country, as in many developing countries, current land use practices are not based on suitability analysis; therefore, there is an urgent need to use land in the most rational and possible way (Assefa,2015).

Food security is not just an economic problem but also a social and political issue relates in the country. Ensuring food security for all is one of the major challenges that our Country (Ethiopia) faces today, production of surplus in the areas like this study conducted (part of Wollo) is one of the problem solve by researches. Research works should do to increase production in the available arable land for achieving optimization of resources relates 
with land suitability assessment (LSA) in this poverty prone areas.

There were a number research works done in title with land suitability analysis regarding Mung bean crop in Ethiopia as well as Amhara regional state reach to the study area of Wollo. Previous studies not satisfy the spatial needs of data in Wollo part of Amhara region in line with the selected crop varieties. Studies like has done by Teame (2018) in Raya valley focused the Mung bean variety adaptation The other study conducted by Aklilu and Abebe( 2020) clearly shown the adaptation of Mung bean varieties with respect to the local performance not touch the spatial productivities of this crop. So the present research clearly shown the potential areas those are suitable for Mung bean crop entirely in the mentioned study area used GIS tools. In order to help local farmers and producers those engaged in Mung bean production detail and site specific spatial suitability analysis for crop productivity is needed to enhance food status of the study area.

\subsection{Objective of the study}

The main objective of the research was to identify and delineate the land that can best support the growth of Mung beans in the whole Wollo, in Amhara Regional state using multi criteria evaluation technique.

\subsubsection{Specific objective}

1) To develop a spatial model for land suitability evaluation for Mung Bean cultivation using GIS tools.

2) To classify agricultural land in the study area into different suitability classes and to develop suitability maps for Mung beans cultivation in Wollo parts.

\section{Research Methodology}

\subsection{Description of the study area}

Wollo part of the Amhara Regional state, here is the study area, extends between $8^{\circ} 40^{\prime} 11^{\prime \prime}$ 'to $14^{\circ} 01$ ' $14^{\prime \prime}$ N latitude, and $35^{\circ} 12^{\prime} 45^{\prime \prime}$ to $40^{\circ} 23^{\prime} 09^{\prime \prime}$ E longitude, with a total area of $42155.32 \mathrm{~km}^{2}$ about $(27.23 \%)$ from the total area of Amhara Region. The area has been mostly encountered erratic rainfall and known with its food insecure part of the country.

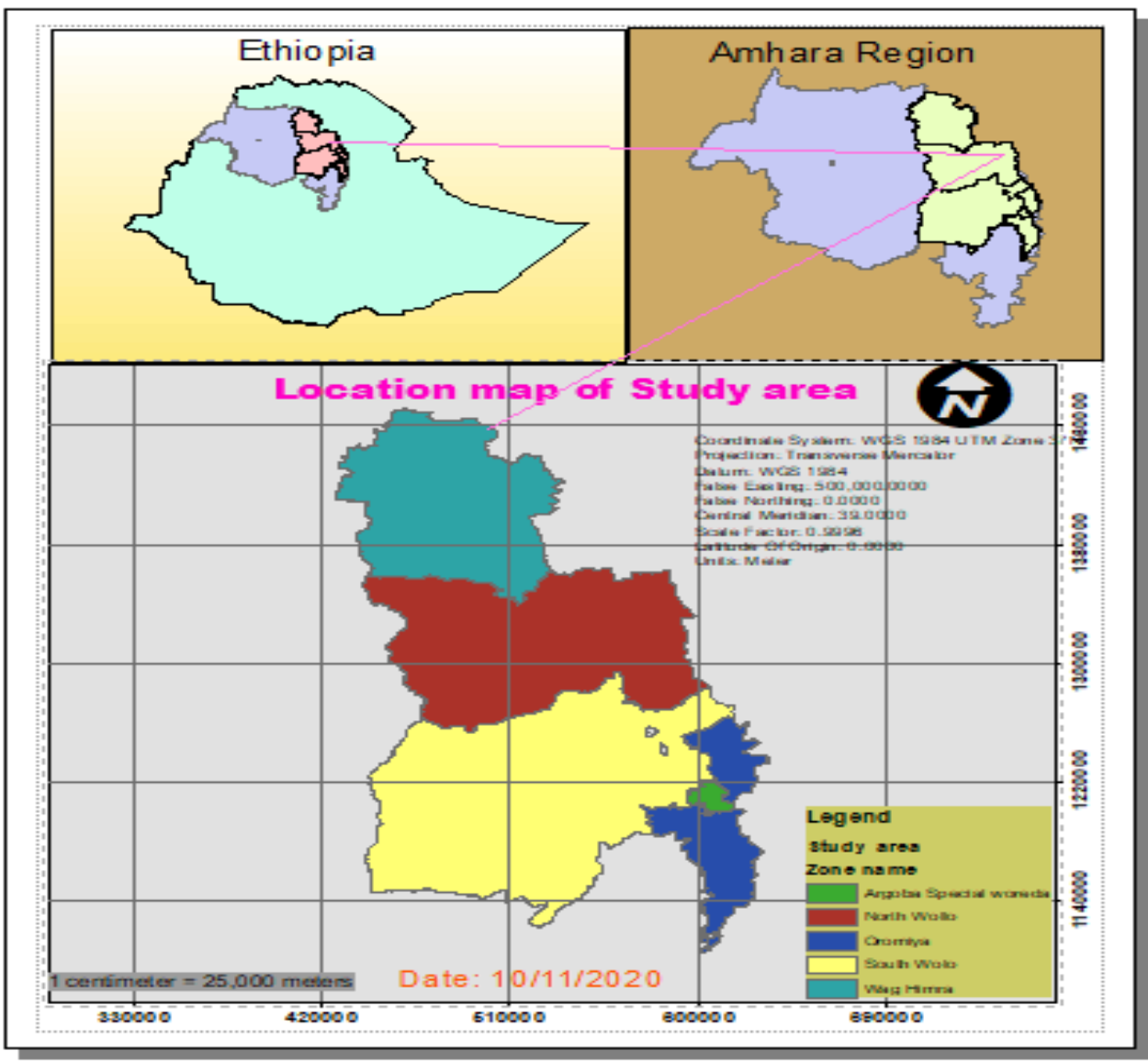

Figure 2:1: Location map of Study area

\subsection{Datasets used}

\section{For the success of this research the following datasets were used.}

1. Satellite Image (Landsat-8 OLI) download from USGS (https://earthexplorer.usgs.gov/) of the year 2020 
used for land use map generation. The path (168,169 and 170) and the row (51, 52 and 53) were applied for this paper.

2. Elevation data

3. Soil data source from FAO (1999) used for soil thematic map preparation.

4. GCP points collected from the farms of the pilot parcel land important for verification of the suitability study within the extent of the study area.

5. DEM (Digital Elevation Model) downloads from USGS digital data menu item importantly acquire for the slope and elevation map preparation.

6. Climate data: The rainfall and temperature datasets of the present study were obtained from World climate data archive (http://www.world.clim.org). In addition to this the stations gauge data of the climate data from 2010 to 2019 access from Kombolcha Meteorological station to make comparison between the clim.org data to the recorded station data types.

For this paper work the whole flow of the research and the types datasets required summarized in the following logical diagram.

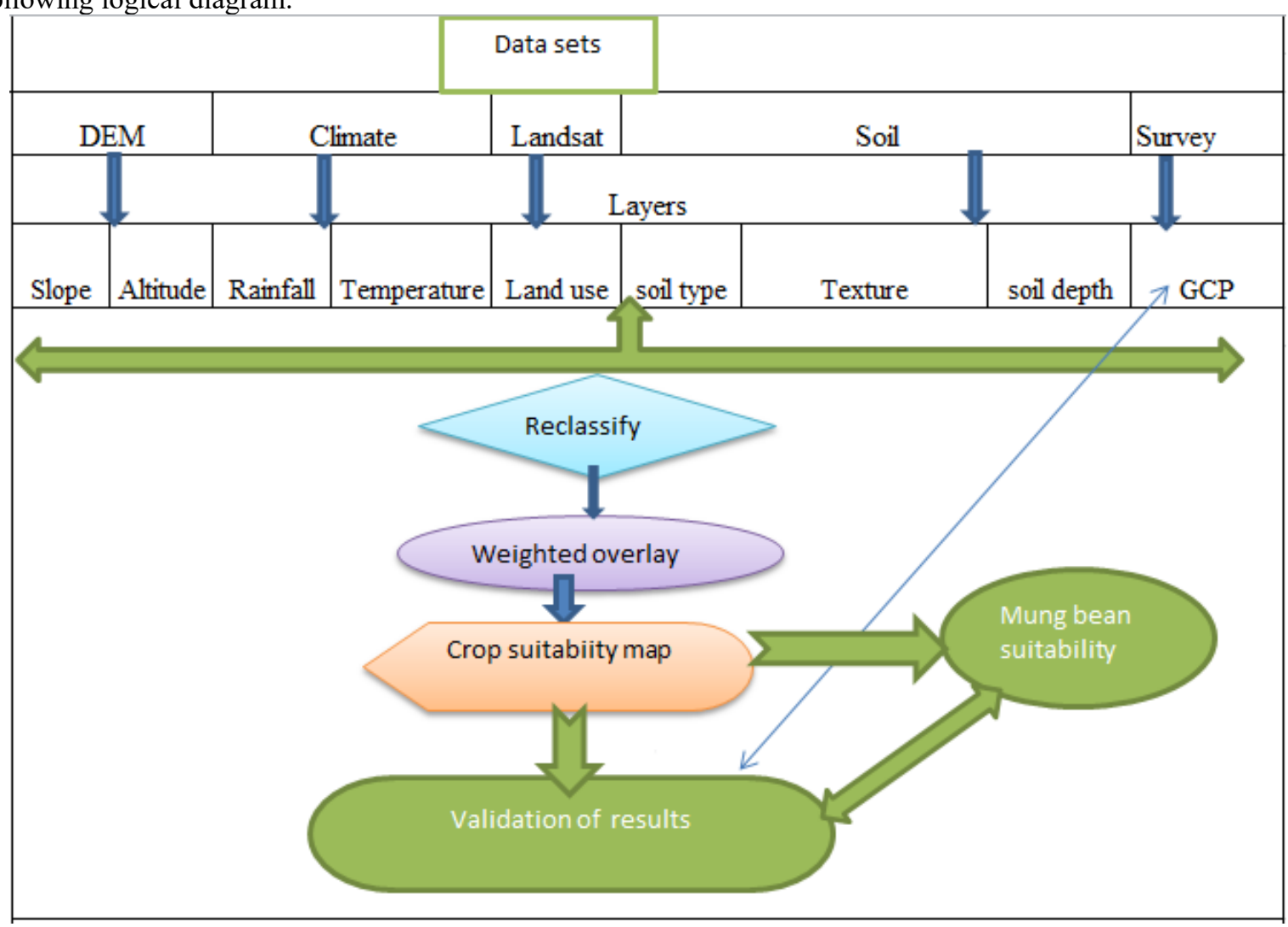

Figure 2: 2: Work flow of the study

\subsection{Software and mapping}

Remotely sensed data (Landsat images), Digital elevation model and soil data was loaded and processed in GIS software i.e. Arc10.5 version and ERDAS 2015 was used for land cover map development .Satellite data of the study area was classified using supervised classification technique and field work information collected from selected sample sites for LULC mapping. Thematic maps of the soil parameter like soil depth, soil type and soil texture class were prepared using ARCGIS tools technique in ARC MAP. AHP was used for calculation of weights for selected criterion.

\subsection{Research methods}

The GIS- based land suitability analysis using AHP (Joerin et al., 2001) approach as the multi-criteria decision analysis (MCDA) was used in this the present study. It allows integrated GIS-based land suitability modeling for site suitability (Mendoza, 1997).

MCDM based AHP methods have used for spatial analysis in agriculture. LSA in the present study can be discussed in six steps i.e. 1) preparation of maps and data base, 2) selection of criterion, 3) ranking, 4) formation of judgments, 5) calculation of assigned ranks, 6) preparation of Normalized Pairwise Comparison Matrix (NPCM) and finally, 7) calculation of weights. 
In this research work, three main criteria were selected for analysis (soil, climate and topography) and 6 sub criteria (soil texture, soil depth, rainfall, temperature, altitude and slope). The criteria were selected based on discussions with crop experts and the information available about Green gram requirements from literature review.

\subsection{Weighting of factors}

The AHP is an intuitive method of decision analysis used in solving MCDM problems and for formulating and analyzing decisions (Saaty 1980; Weiss 1987; Jun 2000; Girard and Toro 2007).

\section{The AHP calculator for factors comparison and Rating}

The AHP online calculator was used for comparison of factors chosen for Mung Bean suitable area study. Calculate priorities from pairwise comparisons using the analytic hierarchy process (AHP) with Eigen vector method. In the present study the following steps were used. First input the number of criteria (they are six in number) with a name for each criterion. Next, do a pairwise comparison: Which of the criterion in each pair is more important, and how many times more, on a one to nine scale. With Check consistency you will then get the

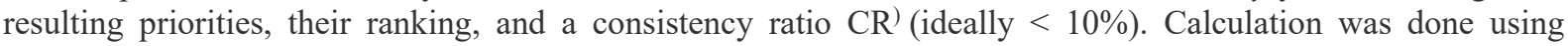
the fundamental 1 to 9 AHP ratio scale.

Table2:1 . Pairwise comparasion of principal factors A - wrt AHP priorities - or B?

Equal How much more?

\begin{tabular}{|c|c|c|c|c|}
\hline 1 & O Soil Depth & Soil Texture & $\mathrm{O}_{1}$ & $\mathrm{O}_{2} \mathrm{O}_{3} \mathrm{O}_{4} \mathrm{O}_{5} \mathrm{O}_{6} \mathrm{O}_{7} \mathrm{O}_{8} \mathrm{O}_{9}$ \\
\hline 2 & O Soil Depth & Rainfall & $\mathrm{O}_{1}$ & $\mathrm{O}_{2} \mathrm{O}_{3} \mathrm{O}_{4} \mathrm{O}_{5} \mathrm{O}_{6} \mathrm{O}_{7} \mathrm{O}_{8} \mathrm{O}_{9}$ \\
\hline 3 & () Soil Depth & Mean Temperature & $\mathrm{O}_{1}$ & $\mathrm{O}_{2} \mathrm{O}_{3} \mathrm{O}_{4} \mathrm{O}_{5} \mathrm{O}_{6} \mathrm{O}_{7} \mathrm{O}_{8} \mathrm{O}_{9}$ \\
\hline 4 & () Soil Depth & Oslope & $\mathrm{O}_{1}$ & $\mathrm{O}_{2} \mathrm{O}_{3} \mathrm{O}_{4} \mathrm{O}_{5} \mathrm{O}_{6} \mathrm{O}_{7} \mathrm{O}_{8} \mathrm{O}_{9}$ \\
\hline 5 & O Soil Depth & Altitude & $\mathrm{O}_{1}$ & $\mathrm{O}_{2} \mathrm{O}_{3} \mathrm{O}_{4} \mathrm{O}_{5} \mathrm{O}_{6} \mathrm{O}_{7} \mathrm{O}_{8} \mathrm{O}_{9}$ \\
\hline 6 & (C) Soil Texture & Rainfall & $\mathrm{O}_{1}$ & $\mathrm{O}_{2} \mathrm{O}_{3} \mathrm{O}_{4} \mathrm{O}_{5} \mathrm{O}_{6} \mathrm{O}_{7} \mathrm{O}_{8} \mathrm{O}_{9}$ \\
\hline 7 & () Soil Texture & Mean Temperature & $\mathrm{O}_{1}$ & $\mathrm{O}_{2} \mathrm{O}_{3} \mathrm{O}_{4} \mathrm{O}_{5} \mathrm{O}_{6} \mathrm{O}_{7} \mathrm{O}_{8} \mathrm{O}_{9}$ \\
\hline 8 & (C) Soil Texture & Oslope & $\mathrm{O}_{1}$ & $\mathrm{O}_{2} \mathrm{O}_{3} \mathrm{O}_{4} \mathrm{O}_{5} \mathrm{O}_{6} \mathrm{O}_{7} \mathrm{O}_{8} \mathrm{O}_{9}$ \\
\hline 9 & (C) Soil Texture & Altitude & $\mathrm{O}_{1}$ & $\mathrm{O}_{2} \mathrm{O}_{3} \mathrm{O}_{4} \mathrm{O}_{5} \mathrm{O}_{6} \mathrm{O}_{7} \mathrm{O}_{8} \mathrm{O}_{9}$ \\
\hline 10 & (O) Rainfall & Mean Temperature & $\mathrm{O}_{1}$ & $\mathrm{O}_{2} \mathrm{O}_{3} \mathrm{O}_{4} \mathrm{O}_{5} \mathrm{O}_{6} \mathrm{O}_{7} \mathrm{O}_{8} \mathrm{O}_{9}$ \\
\hline 11 & (O) Rainfall & Oslope & $\mathrm{O}_{1}$ & $\mathrm{O}_{2} \mathrm{O}_{3} \mathrm{O}_{4} \mathrm{O}_{5} \mathrm{O}_{6} \mathrm{O}_{7} \mathrm{O}_{8} \mathrm{O}_{9}$ \\
\hline 12 & (O) Rainfall & Altitude & $\bigcirc_{1}$ & $\mathrm{O}_{2} \mathrm{O}_{3} \mathrm{O}_{4} \mathrm{O}_{5} \mathrm{O}_{6} \mathrm{O}_{7} \mathrm{O}_{8} \mathrm{O}_{9}$ \\
\hline 13 & () Mean Temperature & Oslope & $\bigcirc_{1}$ & $\mathrm{O}_{2} \mathrm{O}_{3} \mathrm{O}_{4} \mathrm{O}_{5} \mathrm{O}_{6} \mathrm{O}_{7} \mathrm{O}_{8} \mathrm{O}_{9}$ \\
\hline 14 & (C) Mean Temperature & Altitude & $\mathrm{O}_{1}$ & $\mathrm{O}_{2} \mathrm{O}_{3} \mathrm{O}_{4} \mathrm{O}_{5} \mathrm{O}_{6} \mathrm{O}_{7} \mathrm{O}_{8} \mathrm{O}_{9}$ \\
\hline 15 & O Slope & Altitude & O 1 & $\mathrm{O}_{2} \mathrm{O}_{3} \mathrm{O}_{4} \mathrm{O}_{5} \mathrm{O}_{6} \mathrm{O}_{7} \mathrm{O}_{8} \mathrm{O}_{9}$ \\
\hline \multicolumn{5}{|c|}{$\mathrm{CR}=5.2 \% \mathrm{OK}$} \\
\hline \multicolumn{2}{|c|}{ Calculate } & & & \begin{tabular}{|l|l} 
Download_(.csv) $\square$ dec. comma \\
\end{tabular} \\
\hline
\end{tabular}


Table2:2: Result of AHP calculation

\section{Resulting Priorities}

\section{Priorities}

These are the resulting weights for the criteria based on your pairwise comparisons:

\begin{tabular}{|c|c|c|c|c|c|}
\hline Cat & & Priority & Rank & $(+)$ & $(-)$ \\
\hline 1 & Soil Depth & $38.2 \%$ & 1 & $11.2 \%$ & $11.2 \%$ \\
\hline 2 & Soil Texture & $27.5 \%$ & 2 & $11.5 \%$ & $11.5 \%$ \\
\hline 3 & Rainfall & $13.5 \%$ & 3 & $5.3 \%$ & $5.3 \%$ \\
\hline 4 & $\begin{array}{r}\text { Mean } \\
\text { Temperature }\end{array}$ & $9.4 \%$ & 4 & $3.8 \%$ & $3.8 \%$ \\
\hline 5 & Slope & $5.7 \%$ & 5 & $2.0 \%$ & $2.0 \%$ \\
\hline 6 & Altitude & $5.7 \%$ & 6 & $1.5 \%$ & $1.5 \%$ \\
\hline
\end{tabular}

Number of comparisons $=15$

Consistency Ratio CR $=5.2 \%$

\section{Decision Matrix}

The resulting weights are based on the principal eigenvector of the decision matrix:

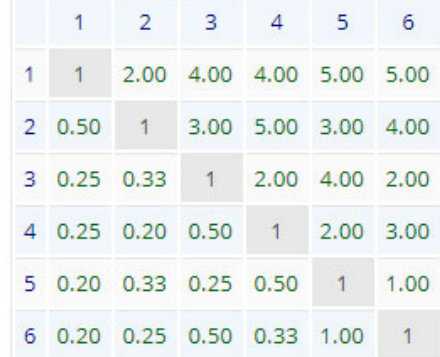

Principal eigen value $=6.328$

Eigenvector solution: 5 iterations, delta $=6.7 \mathrm{E}-8$

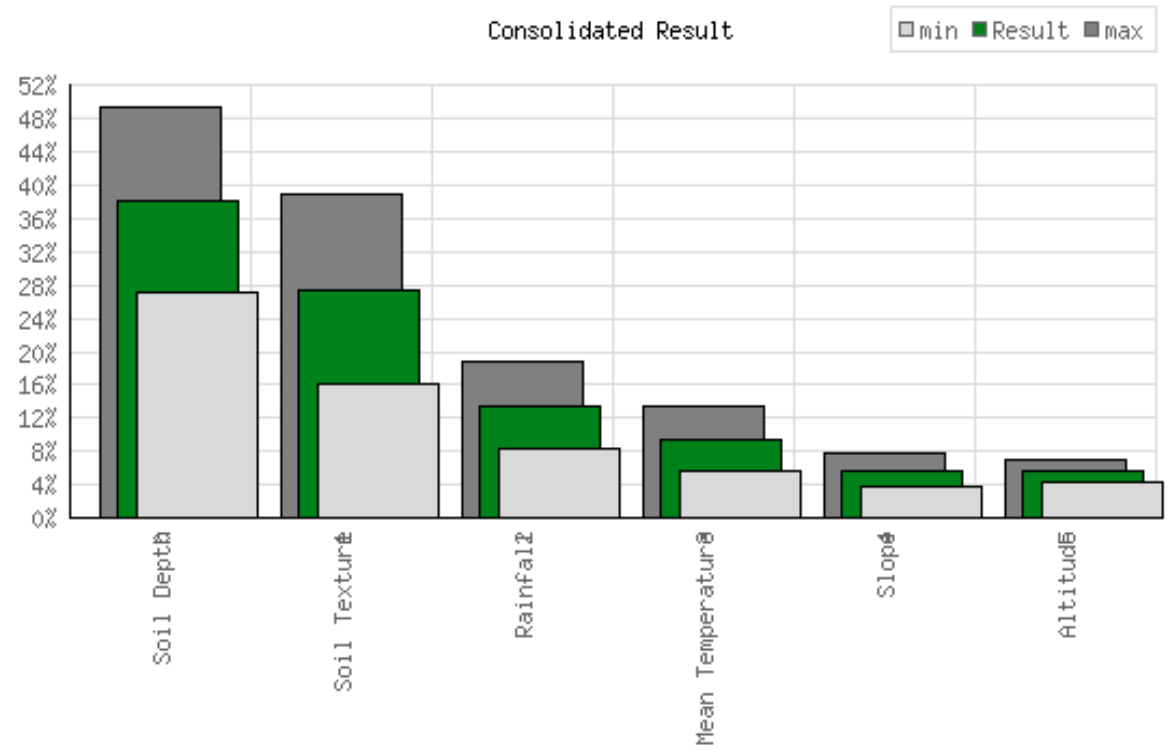

Graph 2: 3: Factors rate and percentage

The weights for the factors from the AHP generated table information (Table 1) and the scores for the alternatives were calculated from the comparison matrices. The weight for factor soil depth was highest $(38.2 \%)$ followed by soil texture (27.5\%), rainfall (13.5\%), Mean temperature (5.7\%), slope and Altitude (5.7). The consistency of the comparison matrix was $5.2 \%$, which suggests that the matrix for the factors was consistent (Since it is less that 10\%). The consistencies of the matrices for alternatives were also within acceptable limit.

The data on suitability of Green gram was summarized into four classes; highly suitable (S1), moderately suitable (S2), marginally suitable (S3) and not suitable (N). Table 2.3 shows a summary of Green gram growing conditions based on reviewed literature and discussions with crop experts. 
Table 2.3: Factors used for Mung bean study

\begin{tabular}{|c|c|c|c|c|c|c|}
\hline \multirow{2}{*}{$\begin{array}{l}\mathrm{S} / \\
\mathrm{n}\end{array}$} & \multirow[b]{2}{*}{ Factors type } & \multirow{2}{*}{$\begin{array}{l}\text { Weight } \\
(\%)\end{array}$} & \multicolumn{4}{|c|}{ Suitability range } \\
\hline & & & $\mathrm{S} 1$ & $\mathrm{~S} 2$ & S3 & $\mathrm{N}$ \\
\hline 1 & Soil & 65.7 & & & & \\
\hline & soil texture & 27.5 & $\begin{array}{l}\text { Loam( sandy } \\
\text { loam) }\end{array}$ & $\begin{array}{l}\text { clayey-Sandy( silt } \\
\text { clay) }\end{array}$ & $\begin{array}{l}\text { V. } \\
\text { Sandy }\end{array}$ & \\
\hline & soil depth(m) & 38.2 & $>0.50$ & 0.5 to 0.3 & $<0.3$ & \\
\hline 2 & Climate data & 22.9 & & & & \\
\hline & Rainfall(mm) & 13.5 & 350 to 600 & 600 to 1000 & $>1000$ & $<350$ \\
\hline & $\begin{array}{l}\text { Mean Temperature } \\
\text { (oc) }\end{array}$ & 9.4 & 12 to 24 & 24 to 27 & 27 to 30 & $>30$ \\
\hline 3 & Topography & 11.4 & & & & \\
\hline & Slope $(\%)$ & 5.7 & 0 to 10 & 11 to 20 & 21 to 35 & $>35$ \\
\hline & Altitude( m) & 5.7 & 1 to 1600 & 1601 to 2000 & & $\begin{array}{l}>200 \\
0\end{array}$ \\
\hline
\end{tabular}

\section{Reclassified factor Results}

Reclassifications maps of respective thematic layers using a common four point scale are shown in various maps summarize in figure 3.2. The most suitable slope falls within 0-10 percent value in the entire study area. Steep slope is not suitable for mung bean production fortunately this is a huge proportion of the study area accounts this type of landscape since Wollo has been know fragile landscape as well as up and down terrain coverage.

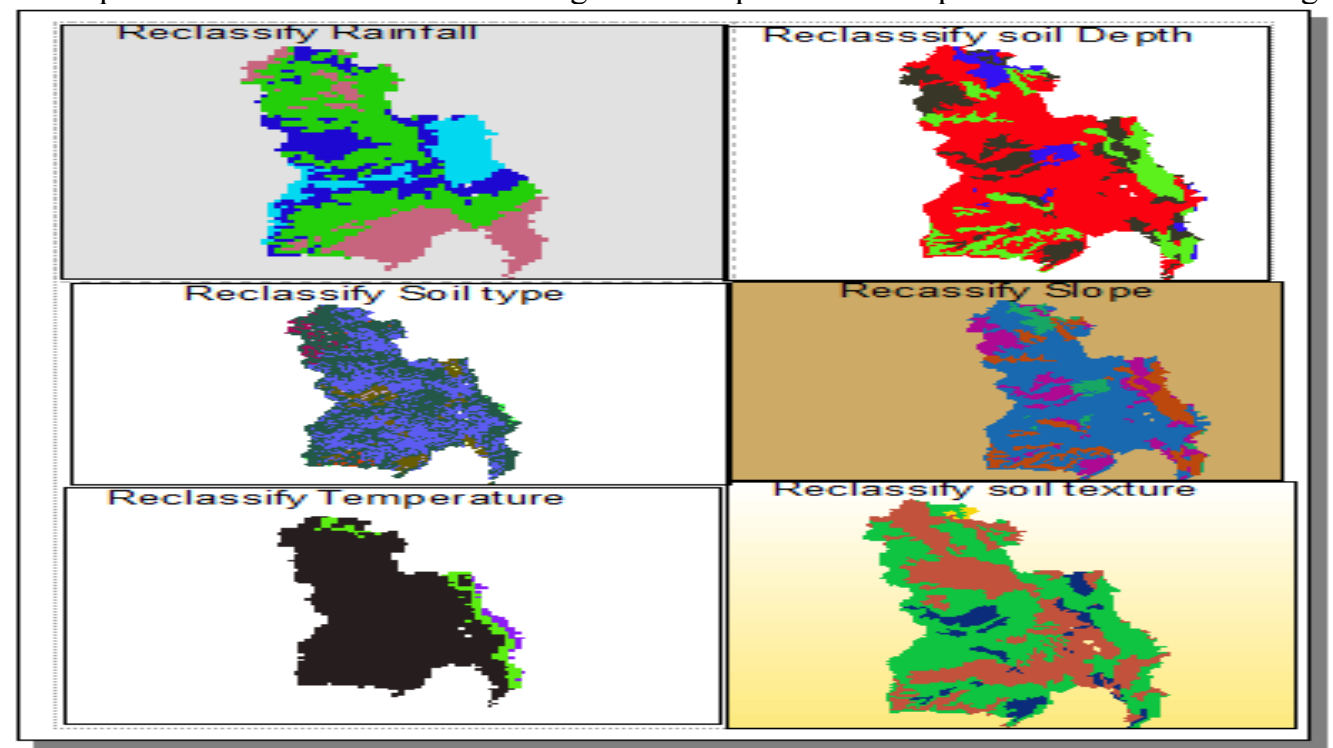

Figure 2.4: Reclassified map layers for Mung Bean

\section{Result of the Study}

\subsection{Land Suitability Classes of Mung bean}

The AHP method was used to evaluate the priority weight of each factor and sub-criteria (parameters). AHP and the Geographic Information System (GIS) are an integrated technique used to assess suitable land for Mung bean production in Wollo territory. In AHP, a weighted overlay method is applied to rank the alternatives according to their suitability for Mung bean suitability analysis.

Land should be used in terms of its capacity to meet human needs and to ensure the sustainability of ecosystems. Improper land use due to changing needs and pressures leads to the destruction of land resources and an increase in poverty and other social problems (FAO 1976; FAO 1977; Duc 2006). Land suitability Classes reflect degrees of suitability. The classes are numbered consecutively, by Arabic numbers, in sequence of decreasing degrees of suitability within the Order. Within the Order Suitable the number of classes is not specified.

Here in the present research work, four types of suitability class were identified for Mung Bean spatial locations suitability study using GIS tools. After all the criteria's weighed and classified using the spatial analysis tools, the suitability of the crop prepared. Four types of classification themes were generated using the FAO (1976) guidelines.

Using the weights generated from AHP for the various parameters, the maps of soil (texture and depth), Climatic factors (climate and Temperature) and topographic (slope and altitude) were overlaid to generate the final 
Green gram suitability map of the Whole Wollo.

\section{Spatial Suitability of Mung Bean Crop}

The classification result of the weighted overlay technique shown that there are four suitable classes in the entire Wollo part to determine the suitability ranges of Mung bean crop.

In the whole study area (South Wollo, North Wollo, Wag-himra, Oromia zone and Argaba special woredas) 291190.11 ha of land (7.21\%) is highly suitable for Mung Bean production. On the other hand from the total areas of this study area $62,846.79$ ha $(1.56 \%)$ is permanently not suitable for Mung Bean production. as it depicted in the map as well as in the graph generated from the study result.

Table: 3:1. Mung Bean Spatial suitability class table

\begin{tabular}{|rlrr|} 
No & Suitability class & Area_ha & \multicolumn{2}{c|}{ Percentage } \\
\hline $\mathbf{1}$ & Highly suitable & 291190.11 & 7.21 \\
\hline $\mathbf{2}$ & Moderately suitable & 2453119.59 & 60.77 \\
\hline $\mathbf{3}$ & Marginally suitable & 1229702.13 & 30.46 \\
\hline $\mathbf{4}$ & Not Suitable & 62846.79 & 1.56 \\
\hline \multicolumn{2}{r}{ Total } & $\mathbf{4 0 3 6 8 5 8 . 6 2}$ & $\mathbf{1 0 0 . 0 0}$ \\
\hline
\end{tabular}

The highly suitable areas administratively located in Oromia zone (Jile Timuga, Artuima fursi, Dewa chefa, Argoba and Bati), South Wollo Zone (Worebabu, Kalu and Wogidi), North Wollo Zone (Habru, Kobo and Gubalafto) and Waghimra( Abergela).

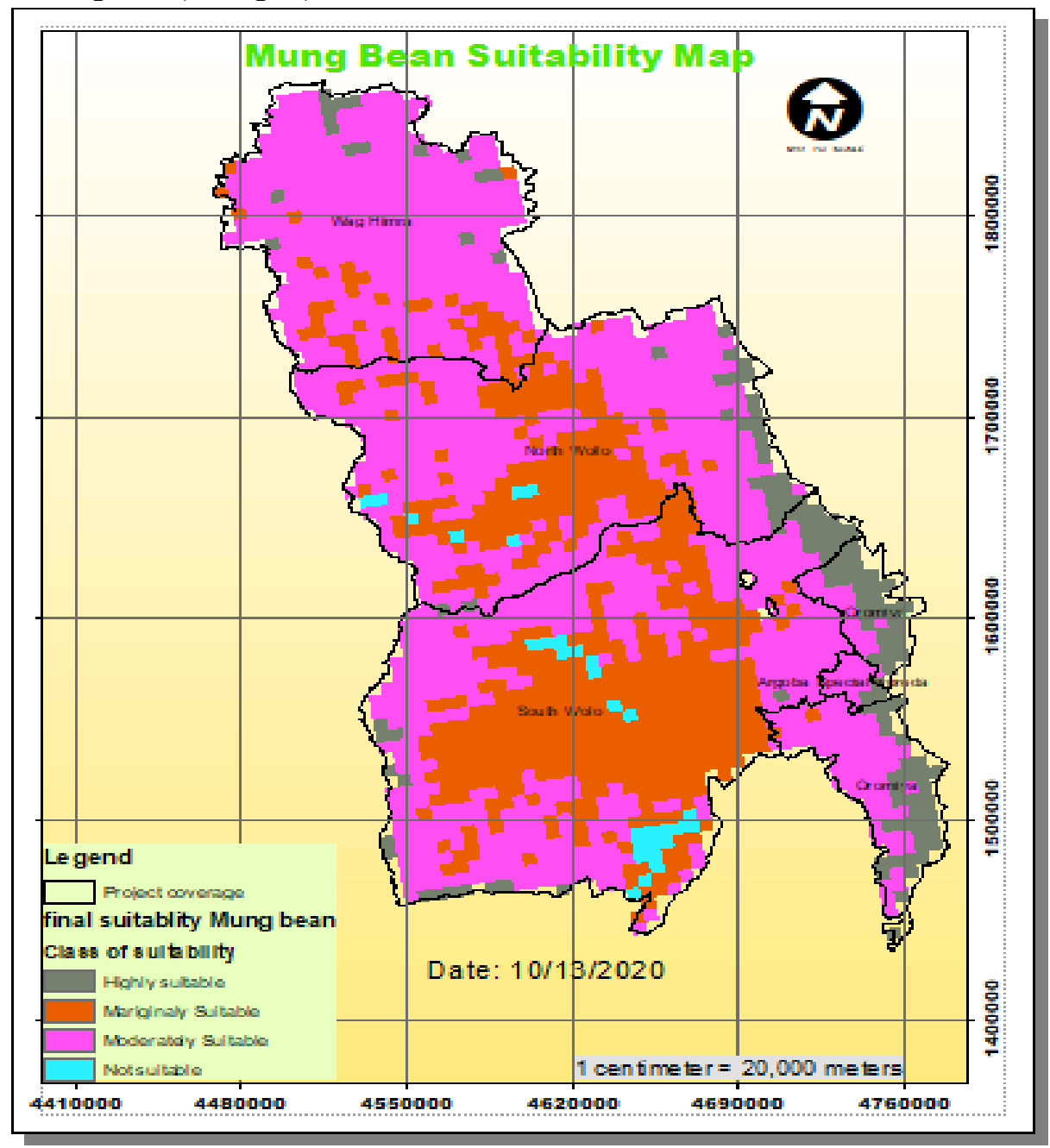

Figure 3.1: Mung bean Suitability map

\section{Conclusion}

The present study was conducted to assess the suitability of the present agricultural lands in the north central Ethiopia specifically Wollo part spatial areas suitability ranges using GIS and AHP approaches. AHP technique was applied to estimate the weights of indicators and sub indicators to account their influences in suitability classification. The final suitability work indicates that $7.21 \%$ has highly suitability, $60.77 \%$ has moderately 
suitability, $30.46 \%$ has marginally suitability, and $1.56 \%$ of the study area has not suitability for Mung bean cultivation practices.

This study can provide a framework for the planning process by using GIS and the multi-criteria decision analysis making (MCDM) approach for the crop Mung bean varieties. It can also provide an important guidance for future land use changes and cost effective solutions in the whole Wollo part as well as provide the same guidance for other Agro-climatic areas beyond the study delimitation.

\section{References}

Aklilu M, and Abebe T , (2020). Adaptation study of mung bean (Vigna radiata) varieties in tepi, south western Ethiopia. Asian Journal of Plant Science and Research ISSN: 2249-7412.

Asfaw A, Gurum F, Alemayehu F, Rezene Y (2012). Analysis of multi environment grain yield trials in mungbean (Vigna radiata L.) Wilczek based on GGE bipot in Southern Ethiopia. Journal of Agricultural Science Technology 14:389-398.

Assfea A. (2015). Land Suitability Evaluation for Sorghum and Barley Crops in South Wollo Zone of Ethiopia. Journal of Economics and Sustainable Development ISSN 2222-1700 (Paper) ISSN 2222-2855 (Online) Vol.6, No.1, 2015.

Ayalew, G. (2015). A Geographic Information System Based Physical Land Suitability

Evaluation to Groundnut and Sweet Potato in East Amhara, Highlands of Ethiopia. Journal of Biology, Agriculture and Healthcare ISSN 2224-3208 (Paper) ISSN 2225-093X (Online) Vol.5, No.1, 35.

Duc T. 2006. Using GIS and AHP technique for land-use suitability analysis. International Symposium on Geoinformatics for Spatial Infrastructure Development in Earth and Allied Sciences, organized by JapanVietnam Geoinformatics Consortium (JVGC) Institute for Environment and Resources, Vietnam.

FAO. (1976). A framework for land evaluation. FAO soils bulletin 32, Rome, Italy.

Joerin, F., Theriault, M., and Musy, A. (2001). Using GIS and outranking multicriteria analysis for land-use suitability assessment. Int. j. of geographical information science, vol. 15, No. 2, 153-174.

MacDonald, J. A. (2006). A Decision-support model of land suitability analysis for the Ohio lake erie balanced growth program. AICP EcoCity Cleveland, pp. 1-50.

Girard LF, Toro P. 2007. Integrated spatial assessment: a multicriteria approach to sustainable development of cultural and environmental heritage in San Marco dei Cavoti, Italy. Cejor. 15:281-299.

Mendoza, G.A. (1997). A GIS-based multicriteria approach to land use suitability assessment and allocation. J.M. Vasievich, J.S. Fried, and L.A. Leefers (eds.). 7th Symposium on Systems Analysis in Forest Resources. GTR-NC-205. U.S. Forest Service, St. Paul, Minnesota

Mulualem A. \& Danaiel A. (2017). Agricultural Land Suitability Analysis for Potato Crop by Using Gis and Remote Sensing Technology, in the Case of Amhara Region, Ethiopia. Journal of Biology, Agriculture and Healthcare ISSN 2224-3208 (Paper) ISSN 2225-093X (Online) Vol.7, No.11, 2017

Saaty,T.L. (2007). Time dependent decision-making; dynamic priorities in the AHP/ANP: Generalizing from points to functions and from real to complex variables. Mathematical and Computer Modeling, 46, 860-891.

Teame G. (2018). Adaptation Study of Mung Bean (Vigna Radiate) Varieties in Raya Valley, Northern Ethiopia 